\title{
MANZUM SÖZLÜK GELENEĞİMİİN KAYIP HALKASI: NAZM-I BEDÎ
}

\section{Mehmet Akif GözíTOK*}

\begin{abstract}
$\ddot{O} \mathbf{z}$
Bu çalışmada, XIII. yüzyıldan XX. yüzyıla kadar bir eğitim öğretim metodu olarak sıkça kullanılan manzum sözlüklerimizin önemli bir halkası olan ve 1224 (m. 1809-10) yılında Maraşlı Çelebizade Ali İlmî tarafından Farsça-Türkçe olarak yazılan, daha önce isminden ve müellifinden başka, hakkında herhangi bir bilgiye sahip olmadığımız Nazm-ı Bedî incelenmiş; bu incelemede eserin muhtevası ve şekil özellikleri ilmî yöntemlerle ortaya konmuş; eserin müellifi Çelebizade Ali İlmî Efendi'nin hayatı ve eserleri hakkında bilgiler verilmiştir.
\end{abstract}

Anahtar Sözcükler: Nazm-1 Bedî, Çelebizade Ali İlmî, manzum sözlük, Maraş.

\section{THE LOST RING OF OUR TRADITIONAL IN VERSE DICTIONARIES: NAZM-I BEDÎ}

\begin{abstract}
This study provides a scientific dissection of a book's content and shape that was a significant example of a teaching method lasted from 13th century to 20th century which is in verse dictionaries- written by Çelebizade Ali İlmi from Maraş as Persian-Turkish in AH 1224 (AD 1809-10) which we have known a tiny bit besides its author and name, Nazm-1 Bedî, additionaly, the author is also mentioned in terms of his life and other works.
\end{abstract}

Keywords: Nazm-1 Bedî, Çelebizade Ali İlmî, verse dictionary, Maraş.

\section{Giriş}

Kelimeler, bir milletin genleridir. Nasıl ki genler bir insanın bütün karakteristik hususiyetlerini kendinde barındırıyorsa kelimeler de bir milletin kültürel hafızasını bünyesinde barındırmakta; o milletin var olabilmesine imkân vermektedir. Bu sebeple kelimelerin varlığı ile milletlerin var olması, varlığını koruyabilmesi noktasında ciddi münasebetler vardır ki kelimeleri / genleri ile oynanmış milletler tarihin şanlı sahnesinden daima kaybolmuşlardır. ${ }^{1}$ Toplumların kültürel hafizası konumunda olan kelimelerin gelecek nesillere aktarılabilmesinde ise en önemli vasıtaların sözlükler olduğuna hiç şüphe yoktur. ${ }^{2}$ Zira sözlükler bir dilin tüm

\footnotetext{
* Arş. Gör.; Erzurum Teknik Üniversitesi Edebiyat Fakültesi Türk Dili ve Edebiyatı Bölümü, makif.gozitok@erzurum.edu.tr.

1 “İmdi dirimsel-türsel kalıtım 'gen' aracılığıyla olurken, toplumsal-millî miras 'yazı' yolundan gerçekleşir. Şu durumda 'gen'i değiştirirseniz, beşerin türe dayalı bireysel bünyesini bozarsınız. 'Yazı'yı başkalaştırırsanız insanın bireysel ve/ya toplumsal varlığını dumura uğratırsınız.” (Ş. Teoman DURALI, Omurgasızlaştırılmış Türklük, İstanbul: Dergâh, 2013, s. 15)"

2 "Sözlük, 'hafıza' demektir, mefhum-ı muhalifiyle sözlüksüzlük ise cinnetle eşdeğerdir." (Ali İhsan Öbek, "Tarihî Türk Sözlükçülügün̈de Dönüm Noktası [Büyük] Türk Lügati”, Turkish Studies International Periodical For the Languages, Literature and History of Turkish or Turkic, 4(4), 2009, s. 846).
} 
kelime varlığını kullanılabilir özellikleri ve tüm incelikleriyle bir araya getiren, bunu geniş okuyucu kitlesinin istifadesine sunan eserlerdir.

Malum olduğu üzere Türk dilinin ilk sözlüğü, Türkçe-Arapça olarak tertip edilen ve Kaşgarlı Mahmud'un kaleme aldığı Divânü Lügati't-Türk'tür. Daha sonra yine Türkçe-Arapça ve Arapça-Türkçe tertiple bazı sözlüklerin yazıldığı görülmektedir: Mukaddimetü'l-Edeb, Tıbyânü'l-Lügati 't-Türk alâ Lisâni'l-Kankli gibi. ${ }^{3}$ Bu ilk dönemlerde Türkçe-Arapça sözlüklerin sayısının fazlaca olmasının, Arapçanın Farsçaya nazaran daha rağbet görmesinin, Türklerin İslamiyetle münasebetlerinin artmasından kaynaklı olduğu aşikârdır. Arapçanın bu etkinliği, Büyük Selçuklu Devleti sultanları Tuğrul Bey, Alparslan ve Melikşah'ın kazandığı zaferlerle hızlanan, Malazgirt Zaferi ile de daha kalabalık kitleler halinde devam eden Türk boylarının göçleri ile bir nebze de olsa azalmıştır. ${ }^{4}$ Farsçanın etkisi ise Gazneliler Devleti ile artmaya başlamıştır. Büyük Selçukluların ilk dönemlerinde Doğu Türkistan'dan Anadolu sinırlarına kadar yayılmış olan Farsça, Türkmen ya da Oğuz boyları aracılığıyla Anadolu'ya taşıımıştır. ${ }^{5}$ Hatta Büyük Selçuklu Devleti'nin bir kolu olan Anadolu Selçuklularında, Farsçaya gösterilen alaka, bu dilde eserler yazma, şiirler kaleme alma zirveye çıkmış; bu devletin yıkılması ile kurulan Anadolu Beyliklerinde özellikle Germiyanoğulları Beyliği'nde daha da artmıştır. ${ }^{6}$ Bunda, eserlerini Farsça yazan büyük ediplerin -özellikle Moğol istilasından kaçıp Anadolu’ya gelen sufi şairler Mevlânâ, Fahreddin-i Irakî, Sultan Veled vb.- etkisinin olduğuna hiç şüphe yoktur. Bir yandan Farsçaya olan ilginin artması; bir yandan da Klasik Türk şiirinin, Klasik Fars şiirinin mazmun, mefhum, gramer ve sözcük dünyasından etkilenmesi; bir yandan da ArapçaFarsça sözlüklerden istifade edilebilmesi gayesiyle ${ }^{7}$ XIV. yüzyıldan sonra Farsça-Türkçe sözlük yazımı oldukça hız kazanmış, pek çok mensur ve manzum sözlük hazırlanmıştır.

Dikkatimizi manzum sözlükler üzerine teksif edecek olursak araştırma neticeleri gösteriyor ki manzum gramer kitapları ve sözlüklere, XI. yüzyıldan itibaren tesadüf edilebilmektedir ki bunların ilk örnekleri Yemenli dilci İsmail b. İbrahim er-Rib'î'nin Kaydü'lEvâbid'i; Zemahşerî'nin el-Mufassal'1; İbn Mâlik'in Teshîlü'l-Fevâid ü Tekmîlü'l-Makâsıd'1;

\footnotetext{
${ }^{3}$ Yusuf Öz, Tarih Boyunca Farsça-Türkçe Sözlükler, Ankara: TDK Yay., 2010, s. 43.

${ }^{4} \mathrm{Öz}, 47$.

5 Öz, 47.

${ }^{6}$ Veyis Değirmençay, Farsça Şiir Söyleyen Osmanlı Şairleri, Erzurum: Atatürk Üniversitesi Yay., 2013, s. 1.

${ }^{7} \mathrm{Öz}, 49$.
} 
Edîb Natanazzî'nin Düstûru'l-Lugâ' 'sıdır. ${ }^{8}$ İki dilli manzum sözlük geleneğinin ilk örneği ise XIII. yüzyıl sözlük yazarlarından olan Bedreddîn Ebû Nasr Mesûd el-Ferâhî’nin Arapça öğretmek için medreselerde ders kitabı olarak okutulan Nisâbu's-Slbyân isimli eseridir. Yine aynı dönemde Nisâbu's-Sıbyân örnek alınarak Şükrullâh b. Şemsüddîn Ahmed tarafından kaleme alınan Zühretü'l-Edeb, iki dilli manzum sözlük geleneğinin ikincisidir. ${ }^{9}$

Tespitlere göre Anadolu'da yazılmış ilk Farsça-Türkçe manzum sözlük ise Hüsam b. Hasan el Konevî’nin 802 (m. 1399-1400) yılında yazdığı Tuhfe-i Hüsâmî isimli eseridir. İlk Arapça-Türkçe manzum sözlük ise Abdullatif İbn Melek'in XIII. yüzyıl sonlarına doğru yazmış olduğu Lügat-i Ferişteoğlu'dur. Bunlardan başka XX. yüzyıla kadar Farsça-Türkçe, ArapçaTürkçe, Arapça-Farsça-Türkçe, Rumca-Türkçe, Fransızca-Türkçe, Ermenice-Türkçe, Bulgarca-Türkçe, Almanca-Türkçe, Boşnakça-Türkçe yaklaşık elli beş manzum sözlük tespit edilmiştir. ${ }^{10}$

\section{1. Çelebizade Ali İlmî Efendi’nin Hayatı ve Eserleri}

\subsection{Hayatı}

Çelebizade Ali İlmî Efendi'nin hayatı hakkında ayrıntılı bilgilere sahip değiliz. Onun hakkında derli toplu malumat veren tek eser, Osmanlı Müellifleri' dir. ${ }^{11}$ Bunun dışındaki tüm çalışmalar, mevcut bilgilerin tekrarı mahiyetindedir. ${ }^{12}$

Çelebizade Ali İlmî, soyu Zeynelabidin ve Hz. Hüseyin'e dayanan; Elbistan'a 1400'lü yılların başında Dulkadiroğulları döneminde, Halep'ten gelen bir aileye mensuptur. ${ }^{13} \mathrm{Bu}$ ailenin

\footnotetext{
${ }^{8} \mathrm{Öz}, 51$.

${ }^{9} \mathrm{O} z, 52$.

${ }^{10}$ Bu sözlükler için bk. Yusuf Öz, Tarih Boyunca Farsça-Türkçe Sözlükler; Ahmet Hilmi İmamoğlu, Farsça-Türkçe Manzum Sözlükler ve Şahidî'nin Sözlüğü, (Yayımlanmamış Doktora Tezi), Atatürk Üniversitesi SBE, Erzurum 1993; Ahmet Remzi Akyürek, Tuhfe-i Remzî, (hz. Ahmet Kartal), Ankara: Akçağ Yay., 2003. Necmettin Yurtseven, Türk Edebiyatında Arapça-Türkçe Manzum Lügatler ve Sünbülzâde Vehbî'nin Nuhbe'si, (Yayımlanmamış Doktora Tezi), Ankara Üniversitesi SBE, 2003.

${ }^{11}$ Bursalı Mehmet Tahir, Osmanlı Müellifleri 1-3, 2(2), İstanbul, 1138, s. 319.

${ }^{12}$ Mehmet Nâil Tuman, Tuhfe-i Nâilî Divan Şairlerinin Muhtasar Biyografileri, (Hz. Cemal Kurnaz, Mustafa Tatc1), C. 2, Ankara: Bizim Büro Yay., 2001, s.697 (2952); Cemil Çiftçi, Maraşlı Şairler Yazarlar Alimler, İstanbul: Kitabevi, 2000, s.147; Lütfi Alıc1, Gülcan Alıc1, Maraşlı Divan Şairlerinden Çelebizade Ali İlmî ve Gebelizade Rahmî, Kahramanmaraş: Noya Medya, 2014, s.17-18; Yaşar Alparslan vd., Türk Edebiyatında Maraşlılar, Kahramanmaraş: Ukde Yay., 2009, s.98; Türk Dünyası Edebiyatçıları Ansiklopedisi, "İlmî", C. 5. Ankara, AKM Yay., 2004 s. 175; Türk Dili ve Edebiyatı Ansiklopedisi, "İlmî Ali Efendi (Çelebizâde)”, C. 4, İstanbul: Dergâh Yay., 1981, s. 371 .
} 
$130^{*}$ TAED 55

Mehmet Akif GÖZiTOK

beşinci kuşaktan torunu olan İbrahim Çelebi ile aile, dört ayrı kola ayrılır ki Maraş’a yerleşen ve Çelebizadeler olarak bilinen Ali Çelebi kolu İlmî Efendi'nin de mensubu olduğu koldur. Şecere şöyledir ${ }^{14}$ :

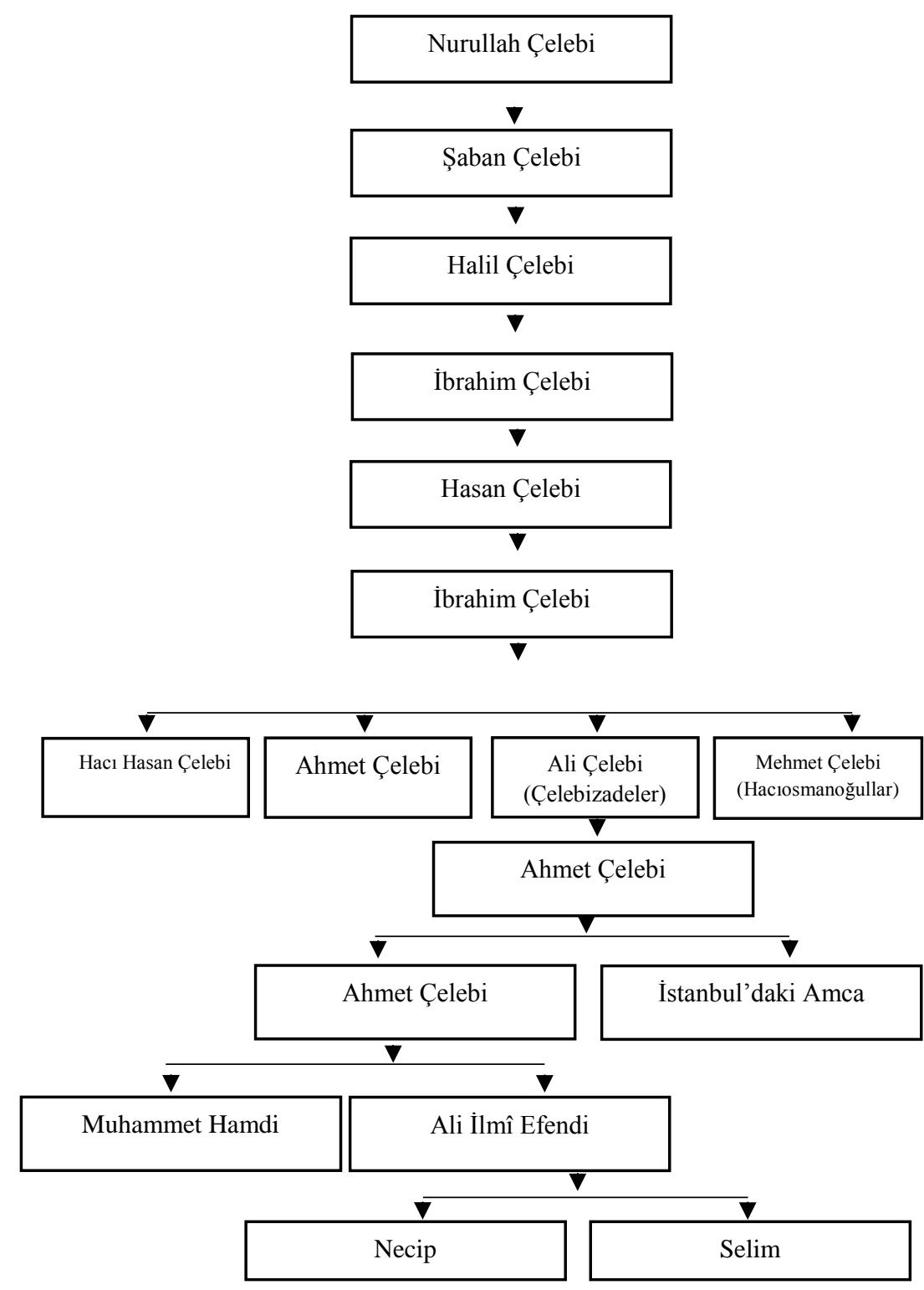

13 Ömer Hakan Özalp, Tuhfe Şârihi Hayatî Ahmed Efendi -Şiirleri, Kütüphanesi ve Tahâfüt-i Müstahrece'si-, İstanbul: Özgü Yay., 2010, s.20, 81, 83; Yaşar Alparslan, Serdar Yakar, Eski Maraş'ta Âlim Çıkarmış Aileler, Kahramanmaraş: Ukde Yay., 2011, s.92.

${ }^{14} \mathrm{Bu}$ şecerenin Ahmet Çelebi’ye kadar olan kısmı Özalp'den iktibas edilmiştir (Özalp, 91). 
Doğum ve ölüm tarihleri hakkında kesin bir bilgi olmamakla beraber bazı manzumelerden hareketle Çelebizade Ali İlmî Efendi'nin doğum ve ölüm tarihlerini tahminî olarak tespit etmek mümkün görünmektedir. Nitekim Hayati Ahmet Efendi ${ }^{15}$ 'nin Bağdat'tan Elbistan'a dönmesi üzerine Çelebizade Ali İlmî Efendi, 22 / 29 Cemaziye'l-ahir 1228 (m. 22 / 29 Haziran 1813) tarihinde ${ }^{16}$ "hoş geldin" redifli bir kaside yazmıştır ki bu kaside, onun o tarihte hayatta olduğunu kanıtlar mahiyettedir. Bununla birlikte içerisinde, adı geçen kasidenin 4 Ramazan 1229 (m. 20 Ağustos 1814) tarihinde istinsah edilmiş bir nüshasının da bulunduğu bir mecmuadaki ${ }^{17}$ şu kayıt, İlmî Efendi'nin 4 Ramazan 1229 (m. 20 Ağustos 1814) tarihinden önce vefat ettiğini göstermektedir: "Merhûm ve magfûrunleh cennet-mekân ve firdevs-i âşiyân Mar'aşî Çelebizâde Alî İlmî Efendi'nin 'ammim (...)". ${ }^{18}$ Buradan hareketle İlmî Efendi'nin Cemaziye'l-ahir 1228-Ramazan 1229 (m. Ağustos 1813-Haziran 1814) tarihleri arasında vefat ettiği kesindir. Çelebizade Ali İlmî Efendi'nin doğum tarihi konusunda ise elde yeterli delil olmamakla beraber 11 Recep 1203 (m. 7 Nisan 1789) tarihinde tahta çıkan ${ }^{19}$ III. Selim için düştüğü tarihten ${ }^{20}$ hareketle İlmî Efendi’nin 1165-1175 (m.1752-1762) y1lları arasında doğmuş olabileceğini tahmin etmekteyiz.

Ali İlmî Efendi'nin henüz bir yaşında iken vefat eden ${ }^{21}$ babası Ahmet Efendi, dönemin Maraş Müftüsü'dür ${ }^{22}$ ve Bursalı Mehmet Tahir'in belirttiğine göre basılmamış mufassal bir Fatiha-i Şerîfe Şerhi vardır. ${ }^{23}$ Babasını erken yaşlarda kaybeden İlmî Efendi’ye, İstanbul'da bulunan amcası yardımlarda bulunmuş daha sonra da ilim kesbetmesi için onu İstanbul'a

\footnotetext{
${ }^{15}$ 1751-2 yılında Elbistan'da dünyaya gelmiş; eğitimine burada başlayıp İstanbul ve Halep’te devam etmiştir. Bir müddet Elbistan müftülüğ̈̈ yaptıktan sonra İstanbul'a giderek Ayasofya medresesinde müderris olmuş; daha sonra iki yıl Saraybosna; iki yıl da Bağdat kadılığı yaptıktan sonra tekrar İstanbul'a dönmüş ve 1814 yılında İstanbul'da vefat etmiştir. Hayatı ve eserleri için $b k$. Özalp, 2010.

${ }^{16}$ Özalp, 34. Ayrıca kaside için $b k$., Özalp, 69-79; L. ve G. Alıcı, 21-27.

17 Özalp'den naklen: Hafız Ali Efendi Yazma Eserler Kütüphanesi, DN Yz 35a-b, 78a-79b. "Bu kaside İstanbul Büyük Ayasofya Medresesi’nde Hayati Ahmed Efendi'nin yeğeni Mustafa b. Süleyman tarafindan yazılmıştır (Özalp, 69).

${ }^{18}$ Özalp, 69; L. ve G. Alıc1, 21.

${ }^{19}$ Kemal Beydilli, “Selim III”, DİA, 420-425.

${ }^{20}$ Cülûs-i şehr-i yâre mu'cemîden İlmî de târîh. Cihân mülkünü teslîm eyledi Mevlâ Selîm Hân'a 1203/1789 (L. ve G. Alıc1, 36).

${ }^{21}$ Bu bilgi sebeb-i nazmdaki şu beyitten hareketle çıkarıldı: Bir yaşında beni terk etmiş idi / Bıraàup Àòirete gitmiş idi $\left(2^{b}, 49\right)$

${ }^{22}$ Bu bilgi sebeb-i nazmdaki şu beyitten hareketle çıkarıldı: "Cedleri Müftì-i meróÿm gibi / Yaènì ol fÀø1l-1 merúÿm gibi" $\left(3^{\mathrm{b}}, 94\right)$

${ }^{23}$ Bursalı, 319.
} 
çağırmıştır. İlmî Efendi bir müddet İstanbul'da ilim tahsil ettikten sonra tekrar Maraş’a dönmüş, bu şehirde müftülük ve Ashab-1 Kehf Medresesi’nde müderrislik yapmıştır. ${ }^{24}$

Çelebizade Ali İlmî Efendi’nin evli ve iki çocuğunun olduğunu incelememize konu olan Nazm-ı Bedî isimli eserin şu beyitlerinden öğrenmekteyiz:

Oḳusun anı Necíb ile Selïm

Anlara ḳ1 bu kitābı teslīm

Yādigār-1 pederimdir o kitāb

Diyerek eyleyeler istiktāb $\left(3^{\mathrm{b}}, 91,92\right)$

Fā`cilātün pederiñ gibi eyā ṭ̂fl-i aṣî̀

Eyle taḥ̦ịil-i ma ārif olagör hayr-1 halef $\left(15^{\mathrm{a}}, 36 / 13\right)$

Nazm-ı Bedî isimli eserin ferağ kaydından hareketle ise Çelebizade Ali İlmî Efendi'nin kardeşinin isminin Muhammed Hamdî olduğunu öğreniyoruz:

“Ketebehu'l-faḳir el-mu' terifi bi'l- aczi ve’t-takṣịiri Muḥammed Ḥamdi dāder-i nāzım

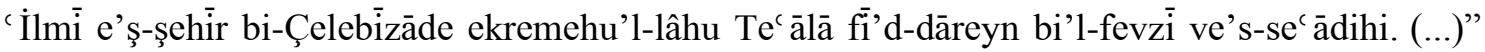
$\left(28^{\mathrm{a}}\right)$

\subsection{Eserleri}

Çelebizade Ali İlmî Efendi’nin biyografik eserlerden öğrendiğimiz kadarı ile iki eseri bulunmaktadır. Bunlar, Şerh-i Tuhfe-i Vehbî ve Nazm-ı Bedî̀dir. Bunun dışında Lütfi Alıcı, Manzûm Ferâiz isimli bir eserinin de olduğunu söylemektedir. ${ }^{25}$ Kanaatimizce bu eserin Çelebizade Ali İlmî’ye aidiyeti biraz şüphelidir ve çabucak verilmiş bir karardır. Zira manzumede eserin Çelebizade İlmî’ye ait olduğuna dair tek bir kayıt dahi yoktur ve de İlmî mahlası ile Manzûm Ferâiz yazanların sayısı da hayli fazladır: İlmî Dede Bağdadî26, Meşrizade İlmî ${ }^{27}$, İlmî Efendi Mehmed Magnisavî ${ }^{28}$, İlmî Remzizade Mehmed $^{29}$, Mermerizade İlmi Efendi $^{30}$ vs. Bu sebeplerle eserin kime ait olduğu müstakil bir çalışmayla araştırılmalıdır.

\footnotetext{
${ }^{24}$ Bu yazma eser Yaşar Alparslan'ın hususi kitaplığındandır. Resim, L. ve G. Alıcı, 70'den alınmıştır.

${ }^{25}$ L. ve G. Alıc1, 19.

${ }^{26}$ Bazı nüshalar şöyle: Amasya Beyazıt İl Halk Kütüphanesi 1853/2; Samsun Vezirköprü İlçe Halk Kütüphanesi Vezirköprü 491/6; Millî Kütüphane Yazmalar Koleksiyonu 3554/26; Köprülü Yazma Eser Kütüphanesi Mehmed Asım Bey Koleksiyonu 727/3; Konya İl Halk Kütüphanesi, 5811/1.

${ }^{27}$ Çorum Hasan Paşa İl Halk Kütüphanesi 172/6.
} 
Yukarıda ismi geçen eserlerin yanı sıra İlmî Efendi’nin şiirlerinin bulunduğu bir cönk, Yaşar Alparslan'ın hususi kütüphanesindedir ve Lütfi, Gülcan ALICI bunları neşretmiştir. ${ }^{31}$

\subsection{1. Şerh-i Tuhfe-i Vehbî}

$\mathrm{Bu}$ eser, Sünbülzade Vehbî’nin kaleme aldığı ve en çok rağbet gören Farsça-Türkçe manzum sözlüklerden biri olan Tuhfe-i Vehb̂̂’nin şerhidir. Eser matbu değildir ve yazma eser kütüphanelerinde yaptığımız ayrıntılı katalog taramalarına rağmen İlmî Efendi’ye ait böyle bir esere tesadüf edilememiştir. Daha önce varlığını Osmanlı Müellifleri’nden ${ }^{32}$ öğrendiğimiz eser, Nazm-ı Bedî'de şu şeklide dile getirilmiştir:

Reh-i nā-reftelere gitmiş iken

Tuhfe-i Vehbỉ'yi şerh etmiş iken

Gelmeyüp țab`a anıñ ile ġınā

Vādīi naẓmda oldum pūyā $\left(4^{\mathrm{a}}, 101,102\right)$

\subsubsection{Nazm-ı Bedî ${ }^{33}$}

Farsça-Türkçe manzum sözlüklerimizden olan Nazm-ı Bedîn ${ }^{34}$, Çelebizade Ali İlmî Efendi tarafindan 1224 (m. 1809-10) yılında telif edilmiştir. Müellifin hatimede, eserin itmamına mücevher olarak düştüğü tarih beyti şu şekildedir:

Ḥarf-i cevherle de tārīhin anuñ

Nāmı olsun ḳo bunuñ Naẓm-1 Bedīc $\quad\left(28^{\mathrm{a}}\right.$, Hatime/9)

$$
1224 \text { نامى اولسون قو بونك نظم بديع }
$$

\footnotetext{
${ }^{28}$ Balıkesir İl Halk Kütüphanesi 1061/01.

${ }^{29}$ Mısır Milli Kütüphanesi Türkçe Yazmaları Ferâizi Türkî 6

${ }^{30}$ Konya İl Halk Kütüphanesi 3280/3.

${ }^{31} \mathrm{Bu}$ şiirler için $b k$. L. ve G. ALICI, 28-51.

${ }^{32}$ Bursalı, 319.

${ }^{33}$ Meşakkatli bir çalışma neticesinde hazırladığımız bu eser, yayımlanma aşamasındadır.

${ }^{34}$ Şair eserine Nazm-ı Bedî ismini koyduğunu, hatimedeki tarih beytinden ayrı mukaddimedeki şu beyitle de dile getirir:

Ḥabbez̄ā oldu bu bir ḥüsn-i șanī

Nām-1 vālāsını ḳoy Naẓm-1 Bedīc $\left(4^{\mathrm{a}}, 114\right)$
} 
$134^{* \text { TAED }} 55$

Mehmet Akif GÖZiTOK

Eser, 115 beyitlik bir mukaddime, 710 beyite tekabül eden 68 kıt'a, 104 ve 12 beyitlik 2 mesnevi ve 9 beyitlik bir hatime olmak üzere toplamda 950 beyittir.

İlmî Efendi'nin Nazm-ı Bedî’nin yazılması hakkında eserin mukaddimesinde verdiği bilgilere göre kendisine küçük yaştan itibaren pek çok ihsanda bulunan amcası bir gün onu karşısına alıp şöyle demiştir: "Ey kardeşimin oğlu İlmî, hüner bahçesinin sünbülü, marifet bağının bülbülü Maraşlı Sünbülzade Vehbî, oldukça renkli, malayani olmayan ve mana yüklü Tuhfe'sini dünyaya taze bir eser olarak bıraktı. Bilirim ki senin karakterin temizdir ve sen Vehbî ile Vassâf'1 da geçeceksin zira sen Çelebi madeninin cevheri, Çelebizadelerin seçilmişisin. Bülbül gibi susma, sen de Vehbî gibi cezbedici ve fasih bir Farsça lügat kaleme al ki onu irfan meclisinin süsü edelim; Necip ile Selim pederimin yadigârıdır diyerek okuyalar, ilim ve irfan öğreneler; dedeleri merhum Müftü gibi bilgili olalar” $\left(3^{\mathrm{b}}, 79-95\right)$.

Bunun üzerine İlmî Efendi de amcasını kırmamak üzere eseri yazdığını şu şekilde dile getirir: "Amcamız böyle nasihat edince düşündüm ve isteğini geri çevirmenin doğru olmayacağına kanaat getirdim çünkü Allâh, Kur'an-1 Kerim'de 'iyi dileği geri çevirme, azarlama' buyurmaktadır. Ben de Allah'ın bu emrine sarılmak gayesiyle elime müşk saçan kalemimi aldım; gidilmemiş yollara gitmiş, Tuhfe-i Vehb̂̂'yi şerh etmiş iken yaratılışıma bunlarla yetinmek hoş gelmedi ve nazım vadisinde yola koyuldum, Vehbî yolunda üslubu hoş, güzel bir eser meydana getirdim" (4⿳a, $96-107)$.

Sebeb-i nazmda eser yazılırken her ne kadar Sünbülzade Vehbî ve Tuhfe'sinin örnek alındığı belirtilse de şair, eserini ondan daha güzel ve daha fazla kelime içerecek şekilde yazdığını da belirtmeden geçememiş̧ir:

Naẓmımı ben de hōoş-üslūb etdim

Ya' nì Vehbì revişinde gitdim

Lìk yazdım nice dürlü ma`nā

Tuḥfe'den belki olupdur ra' nā

Bunda ben hayli fevā'id yazdım

Tuḥfe' den anı zevā'id yazdım (4ª, $107-109)$.

Eser hakkında verilen bu ön bilgilerden sonra eserin şekil ve muhteva açısından incelenmesine geçilebilir. 


\subsection{Eserin Şekil Bakımından İncelenmesi}

\subsubsection{Tertibi ve Kullanılan Nazım Şekilleri}

Manzum sözlüklerin genellikle mesnevi nazım şekli ile yazılmış bir mukaddime ile başlamas1 âdet olmuştur. Nitekim Nazm-ı Bedî de remel bahrinin, fe'ilâtün/fe'ilâtün/fe'ilün vezninde ve mesnevi nazım şekli ile yazılmış 115 beyitlik bir mukaddime ile başlamaktadır. "Besmele"yle başlanan bu mukaddimenin 2 ve 28. beyitleri arasında eserin muhtevasına uygun olarak "kelime" ve "nutk" üzerinde durulan "Hamdele" kısmı; 29 ve 42. beyitleri arasında ise "Salvele" kısmı; 43 ve 46. bölümler arası Ashâb-1 Güzîn'e övgü kısmı gelmekte 47. beyitten sonra ise şairin hayatı, eserini yazış sebebi, eserin ismi vb. bilgileri içerisinde barındıran "Sebeb-i nazm" kismı gelmektedir.

Mukaddimeden sonra ise eserin sözlük kısmı gelmektedir ki bu kısım, 70 kıt'adan müteşekkildir. Bu kıt'aların 68'i, aa, xa, xa ... şeklinde kafiyeli; beyit sayıları 5 ile 19 arasında değişen, vezinleri birbirinden farklı olabilen 'nazm'lardan -mahlas beyti olmayan gazeller de denebilir- meydana gelmiştir. Eserin son kıt'aları olan ve "Ișț1āḥāt-1 'Acem der-Meșnevī", "Meșnevī ebced ḥesābın bildirir" başlıklarını taşıyan 69 ve 70. kıt'alar ise mesnevi nazım şekli ile yazılmıştır. Eserde kıt'alar, revi harflerine göre alfabetik olarak sıralanmış fakat her harften eşit sayıda kıt'a yazılmamıştır. Revi harflerine göre kıt'a sayıları ise şu şekildedir:

Tablo 1: Revi harflerine göre kıt'a sayıları

\begin{tabular}{|c|c|c|c|c|c|c|c|c|c|}
\hline 1 & ب بِ & $ت$ & $\dot{ث}$ & ج ج & $\tau$ & $\dot{\tau}$ & $د$ & $\dot{j}$ & J \\
\hline 3 & 2 & 1 & 1 & 2 & 1 & 3 & 1 & 1 & 3 \\
\hline j & س & ش ش & ص & ض ض & $b$ & ظ & $\varepsilon$ & $\dot{\varepsilon}$ & ف \\
\hline 2 & 3 & 5 & 1 & 1 & 1 & 1 & 1 & 2 & 2 \\
\hline ق & $\Omega$ & 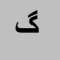 & $J$ & م & ن & و & • & ى & \\
\hline 2 & 4 & 3 & 3 & 2 & 7 & 5 & 4 & 1 & \\
\hline
\end{tabular}

Klasik manzum sözlük tertibine uygun olarak eserde kıt'aları ayıran başlıklar, o kıt'a ile aynı vezin, kafiye ve yine o kıt'anın içeriğini takdim eder mahiyette olan bir mısradır ki bu mısraların 7'si Farsça, 63'ü ise Türkçedir. Mesela içeriği dinî kelimeler olan bir kıt'anın Türkçe başlık mısrası şöyledir:

Kịt ${ }^{\mathrm{c}} \mathrm{a}-1$ şer ${ }^{\mathrm{c}}$ iyyedir revnaḳ-fezā $\left(4^{\mathrm{b}}, 1\right)$ 
Eserde her harfin kıt'a sayısı birbirinden farklı olduğu gibi kıt'aların beyit sayıları da farklılık arz etmektedir. Beyit sayılarına göre kıt'aların tasnifi şu şekildedir:

Tablo 2: Beyit sayılarına göre kıt'aların tasnifi

\begin{tabular}{|c|c|c|c|c|c|}
\hline Beyit Sayısı & Adedi & Kit'a Numarası & Beyit Sayısı & Adedi & Kit'a Numarası \\
\hline 5 beyitli & 1 & 61 & 11 beyitli & 10 & $\begin{array}{l}3,4,7,8,10,26,30,41,42, \\
43,48\end{array}$ \\
\hline 6 beyitli & 2 & 17 & 12 beyitli & 7 & $12,23,38,52,56,62,70$ \\
\hline 7 beyitli & 6 & $1,11,35,37,60,67$ & 13 beyitli & 7 & $14,22,24,36,40,49,59$ \\
\hline 8 beyitli & 7 & $\begin{array}{l}2,15,16,50,53,57,63 \\
6,9,13,18,21,25,28\end{array}$ & 14 beyitli & 2 & 45,64 \\
\hline 9 beyitli & 14 & $\begin{array}{l}32,34,39,44,54,65 \\
66,71\end{array}$ & 15 beyitli & 3 & $19,29,31$ \\
\hline 10 beyitli & 8 & $5,33,46,47,51,55,68$ & 16 beyitli & 1 & 58 \\
\hline 19 beyitli & 1 & 27 & & & \\
\hline
\end{tabular}

Eserin hatime bölümünde ise harflerin ebced hesabındaki rakam değerlerinin yazılı olduğu 12 beyitlik bir mesnevi mevcuttur. Ayrıca eserin itmamına yazılmış olan 9 beyitlik tarih kıt'ası da bu bölümde bulunmaktadır.

\subsubsection{Vezni}

Manzum sözlüklerin yazılış gayelerinin sadece okuyucunun kelime öğrenmesini sağlamak olmadığını daha önce belirtmiştik. Bu eserlerin bir amacı da okuyucuya edebî sanatları, mazmun ve mefhumları, bahir ve vezinleri uygulamalı olarak göstererek okuyucunun şiire ve şairliğe yatkın olan yönlerini ortaya çıkarmaktır. Bu sebeple manzum sözlüklerde edebiyatımızda sıkça kullanılan değişik bahirlerden pek çok vezin kullanıldığına şahit olunmaktadır.

Aşağıdaki tabloda görüleceği üzere incelememize konu olan Nazm-ı Bedî̀ de 6 farklı bahirden 11 vezin kullanılmıştır ki bunlar edebiyatımızda en sık kullanılan vezinlerdendir. Ayrıca eserde okuyucunun, kıt'anın veznini kolayca bulabilmesi ve ezberleyebilmesi için bazı kıt'aların vezinlerinin bütün tefileleri ve bahriyle, kıt'anın son beyitine takti edildiğine tesadüf edilebildiği gibi bazen de tefilenin tamamının yazılmayıp, sadece bir ya da iki tefilenin gösterilmesi ile yetinildiği de görülmüştür. Örneğin:

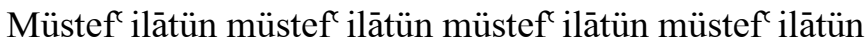

Bu ḳı ț amız da baḥr-i recezden oldu müreffel fikr eyle sen de $\left(24^{\mathrm{b}}, 67 / 7\right)$

Fā' ilātün fā' ilātün oldu miskiyyü'l-hitām

Misk gibi müşk-veş ' anber demekdir şāhbūy $\left(24^{\mathrm{b}}, 68 / 10\right)$ 
Nazm-ı Bedî’ de kullanılan bahir ve vezinler şu şekildedir:

Tablo 3: Vezin tablosu

\begin{tabular}{|c|c|c|}
\hline Bahir & Vezinler & Kit'a Numarası \\
\hline \multirow{4}{*}{ Remel } & $\begin{array}{l}\mathrm{fe} \mathrm{e}^{\mathrm{c}} \text { ilātün } / \mathrm{fe}^{\mathrm{c}} \text { ilātün } / \mathrm{fe} \mathrm{e}^{\mathrm{i}} \text { ilün } \\
\ldots-\ldots / \ldots-{ }_{-} / \ldots\end{array}$ & $\begin{array}{l}\text { Mukaddime, } 14, \\
23,27, \text { Hatime }\end{array}$ \\
\hline & 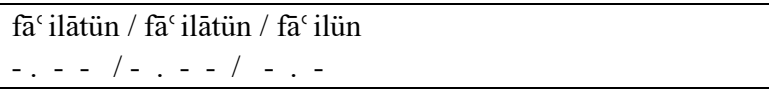 & $\begin{array}{l}1,12,22,55,56 \\
69,70\end{array}$ \\
\hline & 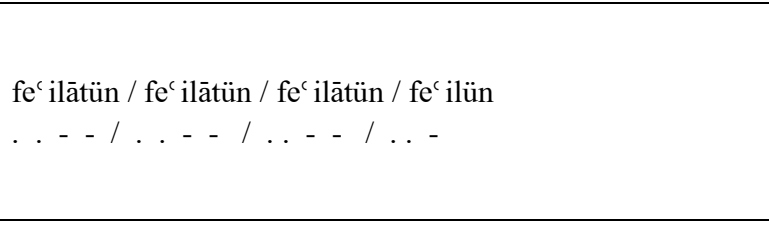 & $\begin{array}{l}5,6,7,10,11 \\
15,21,29,30 \\
31,32,33,36 \\
39,42,43,48 \\
49,50,52,57 \\
59\end{array}$ \\
\hline & 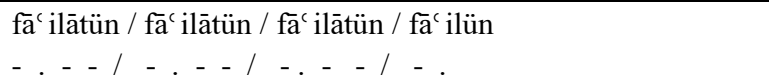 & $\begin{array}{l}20,24,26,28 \\
40,47,64,68\end{array}$ \\
\hline \multirow[t]{2}{*}{ Hezec } & 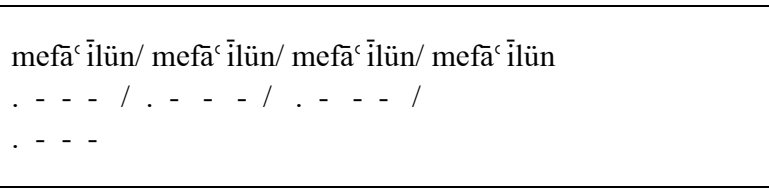 & $\begin{array}{l}2,3,9,13,18 \\
25,35,37,41 \\
45,46,53,54 \\
58,60,61,62 \\
65\end{array}$ \\
\hline & 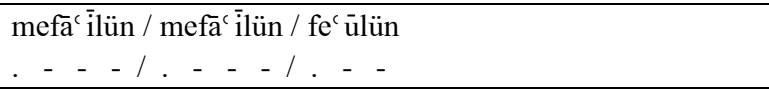 & $4,8,63$ \\
\hline \multirow{2}{*}{ Recez } & 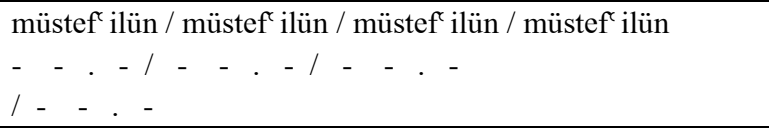 & $16,17,19$ \\
\hline & 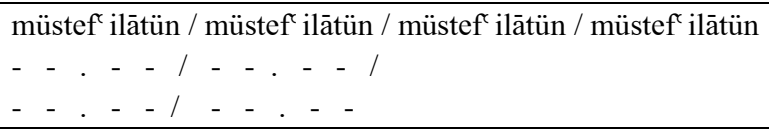 & 67 \\
\hline Kâmil & 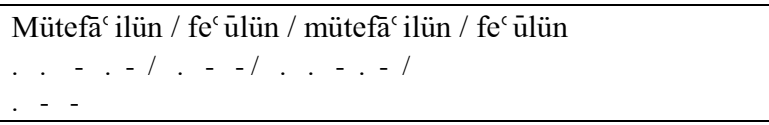 & 34 \\
\hline Muzârî & 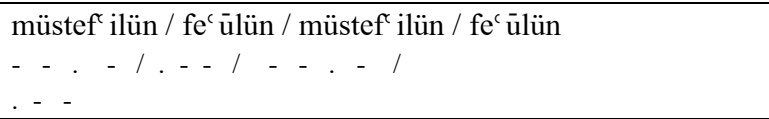 & 38,66 \\
\hline Mütekârib & 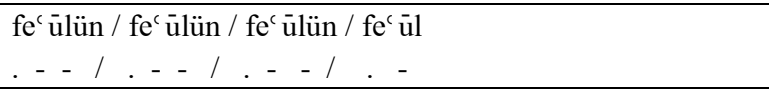 & 44,51 \\
\hline
\end{tabular}

Fakat şunu da açıkça ifade etmek gerekir ki Çelebizade Ali İlmî Efendi, Farsça kelimeleri uygun şekilde metne yerleştirebilmenin gayretiyle olsa gerek vezni ustalıkla kullanamamıştır. Eserin pek çok yerinde vezin hatalarına tesadüf etmek mümkündür. Örneğin

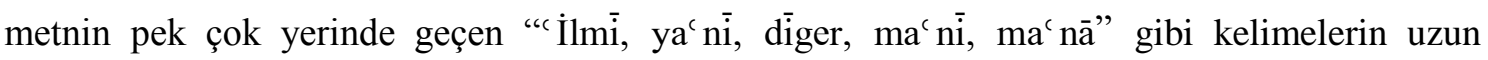

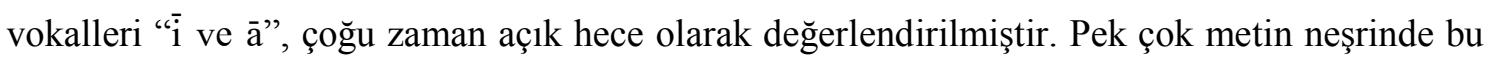
tür kelimelerin uzun değilmiş gibi kısa okunduğuna şahit olunsa da biz bunu, şairin aruzu ustaca kullanamaması olarak yorumladık. Çünkü bu bir aruz kusurudur ve pek de makbul olmadığı kaynaklarda geçmektedir. Eğer selef bunu bir kusur olarak addetmeseydi isim koyma zahmetine dahi girmezdi. Yine eğer müstensih hatası değil ise -ki başka nüsha olmadığı için 
$138^{*}$ TAED 55

Mehmet Akif GÖZiTOK

karşılaştıramadık- fe'ûlün/ fe'ûlün/ fe'ûlün/ fe'ûl vezninin son tefilesi "fe'ûl'ün, üç ayrı yerde “fe'ûlün” şeklinde kullanıldığı görülmektedir. ${ }^{35}$

\subsubsection{Kafiyesi}

Didaktik eserlerde, şairde metni şiire dönüştürme gayreti ön plana çıtığı için veznin, edebî sanatların, kafiyenin geri plana itildiği hatta bazen terk edildiği görülebilmektedir. Bu sebeple bu didaktik eserlerin, özellikle de manzum sözlüklerin edebî değerleri kıymetlendirilirken başka kriterlere başvurulmalıdır.

Nazm-ı Bedî̀'de en çok ن harfiyle kafiyeli kıt'a vardır ki bunların toplamı yedidir. Onu ذَ, ض, ص, ط ط beş ayrı kıt'ada kafiye olarak kullanılması ile و ظ, ظ,

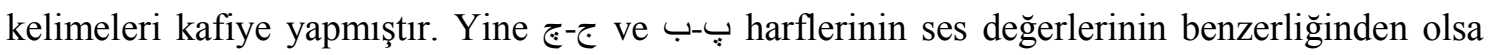
gerek şair, bunları ayrı ayrı kafiye yapmamış aynı kıt'a içerisinde kullanmıştır. Şairin takdir edilecek bir yönü olarak şunu söylemek gerek ki bütün harflerle tüm kafiye türlerine birer örnek vermiştir. Eserde kullanılan kafiye türlerinin kıt'alara göre tasnifi aşağıdaki gibidir:

Tablo 4: KafiyeTürleri

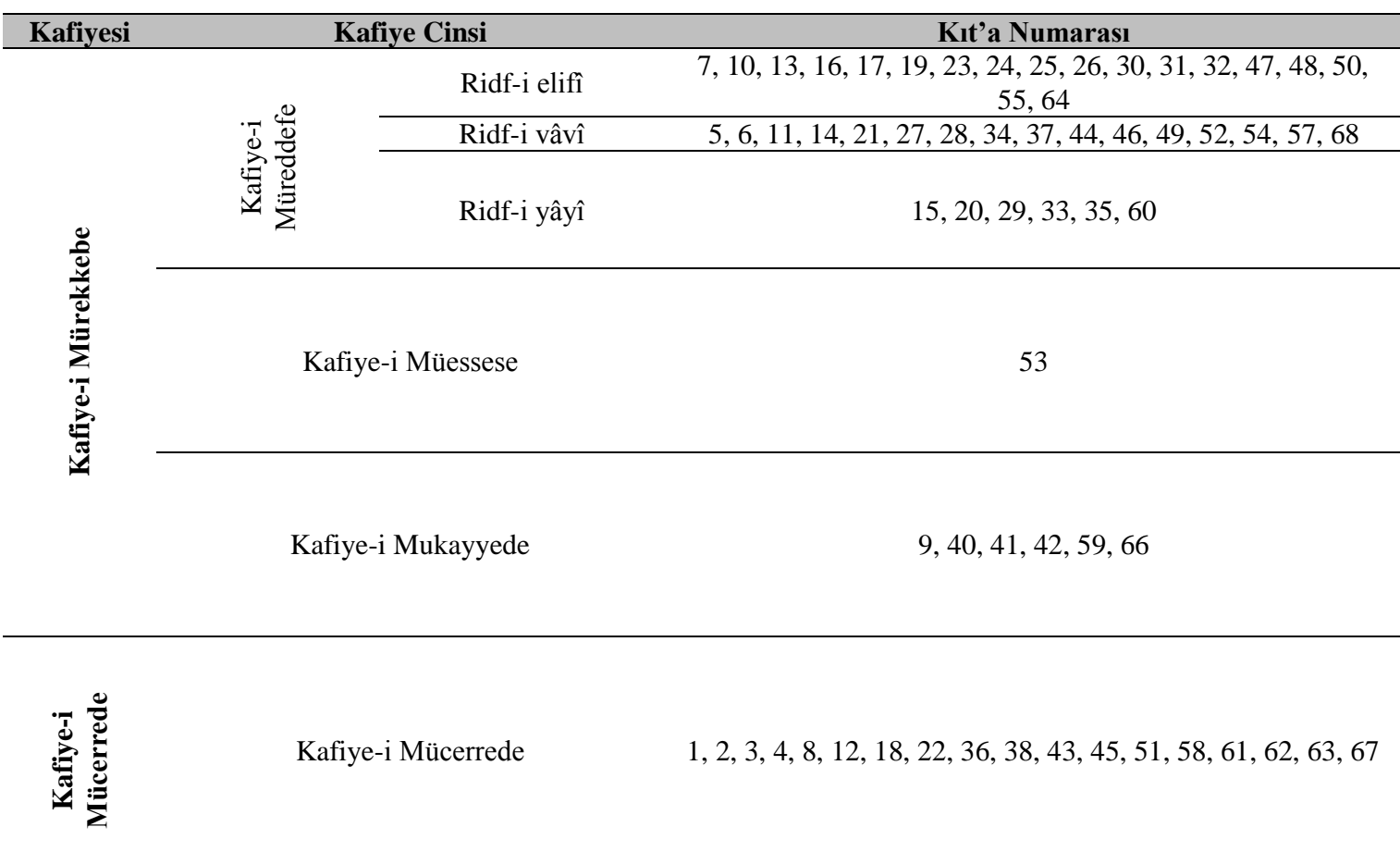

${ }^{35}$ bk. $17^{\mathrm{b}}, 44 / 3,44 / 4 ; 19^{\mathrm{b}}, 52 / 8$ 


\subsection{Eserin Muhteva Açısından İncelenmesi}

\subsubsection{Muhtevası}

Çelebizade Ali İlmî Efendi'nin Nazm-ı Bedî isimli eseri, manzum sözlüklerin genelinde olduğu gibi çoğunlukla isim, fiil ve sıfat türünden kelimeleri içermesinin yanı sıra fiillerin mazi, müzari hallerini; çekimli isim ve fiilleri, deyimleri hatta cümleleri de içermektedir. Buna ilaveten Çelebizade Ali İlmî Efendi eserinde, bazı manzum sözlüklerde de görüldüğü üzere dinî terimlere, tasavvufî̀ sstılahlara, edebî bilgilere -mazmun, kinâyât, telmih vb.- kelime gruplarına da yer vermiştir. Bu sebeplerle Nazm-ı Bedî, oldukça zengin bir muhtevaya sahiptir.

Eserde 1993 adet isim, fiil ve sıfat; 176 adet deyim; 97 adet çekimli isim ve fiil bulunmaktadır. Eserin toplam kelime sayısı 2266'dır. Fakat şunu açıkça ifade etmek gerekir ki eserdeki kelimelerin başlangıç seviyesi için olmadığı kanaatindeyiz. Eserin okuyucu için seçtiği kelime kadrosundan anlaşıldığı kadarıyla bu eser yetişkinler için kaleme alınmıştır. Bunu eserin kaynaklarından anlamak da mümkündür. Zira içinde nadir kullanılan kelime ve anlamların bulunduğu Burhan-ı Katı'nın; yine Dihudâ'da dahi bulamadığımız kelimeler barındıran Lehcetü'l-Lügat'ın, mübtedinin kullanacağı sözlükler olmadığı kanaatindeyiz. Mesela "korkmak" kelimesinin karş1lığı olarak Farsça'da kullanılan en yaygın kelime "ترسيدن" (tersîden)'dir ve mübtedilere ilk öğretilmesi gereken kelimenin de o olması gerektiğini düşünüyoruz. Oysa şair bunun yerine şu kelimeleri yazıyor:

Ḳorḳmaḳ şemīden hem heyālïden hırāsīden gibi

Dahi nehāviden imiş ḩavfa denilmişdir nihāz $\left(9^{\mathrm{b}}, 19 / 9\right)$

Yine "salınarak yürümek" manasına gelen en yaygın Farsça kelime, "خراميدن" (hırâmîden) iken şairin, bu manada esere aldığı kelimeler şunlardır:

\section{Denīden dahi pahsīiden kurāzīden u lencīen}

Tebahtürle yürümek oldu naz u şive ganc u munc $\left(6^{\mathrm{b}}, 9 / 6\right)$

Bunların sayısını çoğaltmak mümkündür. Fakat biz başka bir yönden de eserin yetişkinler için yazıldığını göstermek istiyoruz. Eserde bırakın çocukları, yetişkinler için dahi müstehcen olan pek çok kelime kullanıldığına ve bu müstehcen kelimelerin kinayelerinin de verildiğine tesadüf edilmektedir. Örneğin; hiç kimsenin, çocuklara kelime haznesi gelişsin diye erkek ve kadın tenasül uzvu isimlerinin, çocuklar için bilinmesi gerekmeyen pek çok müstehcen 
kelimenin ayrıntılı eş anlamlılar listesini çıkaracağına inanmıyoruz. ${ }^{36}$ Bütün bu sebeplerden hareketle Nazm-ı Bedî̀nin, çocuklar için değil, yetişkinler için yazıldığı kanaatindeyiz.

Eserde ayrıca, okuyucunun Farsçanın cümle yapısını görmesi için dört kıt'ada, ilk mısrası Türkçe ikinci mısrası Farsça veya Arapça olan beyitler de bulunmaktadır:

Bizim içün ḳapu aç ey Açıcı cennetden

Uftiḥa'l-bābe mine'l-huldi lenā yā Fettāḥ (7a , 7/11)

Böyle revnaḳlı suhenler söylerim saña işit

İ̀n çonin rengīn suhenhā bā to mi gūyem benūşs $\left(12^{\mathrm{b}}, 28 / 9\right)$

\subsubsection{Dil ve Üslubu}

Nazm-ı Bedî, didaktik bir eser olması hasebiyle sade bir dile sahiptir ve eserde arkaik kelime sayısı fazla değildir. Hem kıt'alarda hem de beyitlerde kullanılan kelimeler, akılda kolay tutulabilmesi için konu ve anlam ilişkisi açısından ya birbiriyle alakalı, yakın yahut zıt anlamlı kelimelerdir. Mesela eserin 18. kıt'asının tamamı akrabalık isimleri ile alakalı olduğu gibi beyit içerisinde de belirli bir düzen söz kosunusudur:

Peyer baba birāder dāder ü āmūcedir evder

Anaya mām de hāāū țayıdır hem yegen ahder $\left(9^{\mathrm{a}}, 18 / 1\right)$

Gülmek imiş ḩandiden ü handīd güldü demedir

Hājīden oldu ag̉lamaḳ ağla demek imiş behāj $\left(9^{\mathrm{a}}, 19 / 2\right)$

Yine müellif, klasik manzum sözlük üslubuna uygun bir şekilde, okuyucunun mısrayı, beyiti kolay ezberleyebilmesi için merhun beyit yazmamaya gayret etmiştir.

\subsection{Eserin Kaynakları}

Manzum sözlük müellifleri eserlerini kaleme almadan önce mensur sözlüklerden kelime derleme çalışmalar yapmışlar ve daha sonra derledikleri kelimeleri nazmetme yoluna girmişlerdir. Bu bakımdan manzum sözlüklerin kaynakları mensur sözlüklerdir. ${ }^{37}$ Çelebizade Ali İlmî Efendi de Nazm-ı Bedî isimli eserini kaleme almadan önce Mütercim Asım Efendi’nin

\footnotetext{
${ }^{36}$ Bu kelimeler için bk. (5/2), (7/5), (10/1), (12/5), (24/5), (24/6), (24/7), (25/7), (49/2), (49/3), (50/1), (65/1).

${ }^{37}$ Öz-B, 71.
} 
telif-tercüme eseri Tıbyân-ı Nafì der-Tercüme-i Burhân-ı Kat'ı ${ }^{38}$ ve Şeyhulislam Esad Efendi'nin Lehcetü'l-Lügat ${ }^{39}$ isimli mensur sözlüklerinden derlemeler yapmış, eserin kelime kadrosunu oluşturmada bu eserlerden istifade etmiştir. Nitekim mukaddimede bu bilgi şöyle geçmektedir:

Naẓmımıñ şāhidi Tibyān oldu

Elde hü̈ccet gibi Burhān oldu

Yazdıġım Lehce vü Tibyān'dandır

Bu cevāhir ol iki kāndandır (4a , Mukaddime/111-112)

Şair, kimi zaman hangi kelimeyi hangi kaynaktan aldığını da açıkça yazmaktadır:

Rātiyān çām saḳızı zifte denür şāmāke

Yazdı Burhān' da ḳațrānıñ adını şurpūn (21 b, $57 / 6)$

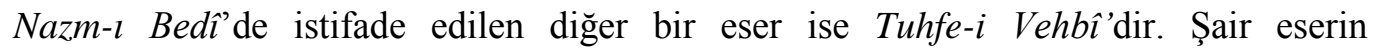
mukaddimesinde, daha önce bu eseri şerh ettiğini; onunla yetinmeyip onun gibi hatta ondan daha güzel bir eser kaleme almak istediğini belirtir. Bu etkilenmenin dışında eserde Tuhfe-i Vehbî̀nin kaynak eser olarak da kullanıldığı görülmektedir:

Tuḥfe-i Vehbī de yazmış "Cām rā ber seng zen"

Tevbe eyle demeden olmuş kināye șuç gunāh $\left(23^{\mathrm{b}}, 64 / 13\right)$

\section{4. Nazm-1 Bedî den Örnekler}

1

$4^{\mathrm{b}}$ Kit ț a-1 şer` iyyedir revnaḳ-fezā

fấ ilātün / fấ ilātün / fấ ilün

$-.-1-. .1-$.

1 Tañrı adı ile bā-nām-1 Hुudā

Kerdeem āgāaz ḳıldım ibtidā

Hem dahị ḥamd u șenā olmuş sipās

\footnotetext{
${ }^{38}$ Mütercim Asım Efendi, Burhan-ı Katı, (hz. Mürsel Öztürk, Derya Örs), Ankara: TDK Yay., 2009.

${ }^{39}$ Şeyhülislam Mehmed Esad, Lehcetü'l-Lügat, (hz. Ahmet Kırkkılıç), Ankara: TDK Yay., 1999.
} 
Kerden etmekdir hemişse dā 'imā

Tañrı'ya İ̉zed denür Yezdān-veş

Oldu şod pā-beste sāait bīfenā

Uyucu peyrev peyamber'dir resūl

Bāverende oldu Mü'min bil aña

5 Hāvuş ümmet hem cemā' atdir gurūh

Uyulan kesdir efendi pişvā

Mescide mezgit denür bang-1 namāz

De ezāna hem durūd oldu du' à

7 Fā' ilātün kāâiye servāre'dir

Veznile buldu bu kit ${ }^{c}$ am intihā

15

$8^{\mathrm{b}}$ Kiț ${ }^{\mathrm{c}} \mathrm{a}-1$ zāal'’ oḳu oldu şekerden de leżiz

$\mathrm{fe}^{\text {c } i l a ̄ t u ̈ n ~ / ~ f e ~ i l a ̄ t u ̈ n ~ / ~ f e ' ~ i l a ̄ t u ̈ n ~ / ~ f e ~ c ~ i l u ̈ n ~}$

$\ldots-1 \ldots-1 \ldots-1 \ldots-$

1 De șig̀ınmag̀a funūden 'Arabīsi ta' vīz

Rukye efsūn u fusūn oldu misāl-i te 'hīiz

Nātuvān ḳuvveti yoḳdur deme mānend-i ża î if

Dahi ḳuvvetsize bīzūr denür miṣl-i vaḳizz

Dāşten dutmagia denildi temessük-āsā

Atmaḳ endāḩten u öyle demekdir tenbīz

Yüce bālā deme ma' nāsına yüksek ‘ālâ

Tīg̀-i kūh oldu țag̀ıñ sivrisi öyle ḥınzīiz

5 Ḳul demek bende vü lāçin dahi ' abd u medīn

Hem girifte de țutulmuş ḳula mānend-i ahīz 
Der şoden girmege denildi o ma' nāda duhūī

Gozerānīden imiş ya ni geçirmek tenfīz

HŨāce üstād $^{40}$ demek oldu mu' allim-āsā

Dahi şākirdiñ adı oldu efendi tilmīz

8 Fārisī vü 'Arabì ile ḳarışmış suhenim

Oḳuyana gelür ol şīr ü şekerden de lezīiz

\section{7}

$15^{\mathrm{b}} \mathrm{Bu}$ ḳt $t^{\mathrm{c}}$ am yād eden elbet ma ārifle olur ma' rūf

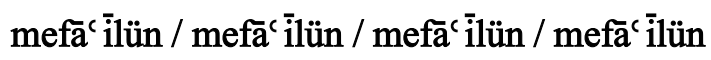

1 ' Aṣāsı elde misvākı belinde arḳasında șūf

Mürāyi șūfīdir sālūs öyle olma sen mevșūf

Dahi çirk-i riyādan pāk-dāmen pārsā olmuş

$\mathrm{O}$ ‘ārifdir degil ḩalḳñ miyānında bili ma‘ rūf

Muḥib ma' nāsı feylā ḥikmete hem sūf denmişdir

Ḥakīmiñ 'ilme ḥubbu oldug̉uyçün dendi feylāsūf

Denildi būm bayḳuşa 'imārat düşmanı ḳuşdur

Dahi ol būm-1 şūmuñ būf derler ismine hem nūf

5 Ügüye būma çūkek derler aṣhạāb-1 luggāa ammā

Ügü kuf pek büyügü adına derler anı̃ harkūf

Yaşamış sālhorde hem bunamışdır dahi fertūt

Koca ḳarıya konde pīr denmiş öyledir hem țūf

7 Mefāc ìlün mefāc î̀ün denür hebyūn afyona

Feḥamden sümme ḥamden ${ }^{41}$ olmadım anıñla ben me 'lūf

${ }^{40}$ Metinde “"اسداد" şeklinde yazılıdır. 
$21^{\text {b }}$ Oldu bu ḳț $t^{c} a-1$ ra' nā da çü dürr-i meknūn fe' ilātün / fe ilātün / fe' ilātün / fe i ilün $\ldots-1 \ldots-1 \ldots 1 \ldots-$

1 Dendi cin țutmuşa sāyezede ya ni mecnūn Oldu dīiāne deli ḳayda sezādır o cünūn Añla āzūn demek ancılayın ma' nāsı

Bunculayın deme mefhūmu da olmuş eydūn

Rengden renge girer bu mütelevvin ḥayvān

Dehre teşbīh olunur adı imiş būksalemūn

Muṭlaḳā esb ata dendi yola lāyı̣ rehvār

Dahi ma şūḳa-1 Ferhād'ıñ atıdır Gulgūn

5 Baṣḳın etmek deme ma' nāsı şebihhūn kerden Gece çāpūlunuñ adına denildi şebhūn

Rātiyān çām saḳızı zifte denür şāmāke Yazdı Burhān’ da ḳațrānıñ adını şurpūn

Çörek otuna de sīsān u yüzerlik de sipend Kekike dendi şuturpā dahi zīre kemmūn

8 Fā`ilātün fe ilātün şu benim manzūmem Rişte-i naẓmda mānende-i dürr-i meknūn 64

$23^{b}$ Kiț a-1 hā'da muvaffak ḳıldı bu 'abdin İlâh fāc ilātün / fầ ilātün / fâc ilātün / fầ ilün

- . - I - . I _ . I - -

"فحمدا ثم حمدا، (Sonsuz hamd olsun) 
1 Ṣāḥib-i taḩt u serīire dendi şimdi pādişāh

Șūret-i ma` nāda mislinden olan mümtāz şāh

Pādişeh kişver-Hudā'dır hāan-1 hānān hem vezir

Dahi mollā' dır efendi mīr beg ' asker sipāh

Oldu būb endīin ${ }^{42}$ çadır perve-āsā mac nìde

Pek büyük çadır demek ḩargāh otāḳdır bārgāh

Pāygāh olmuş pābūçluk ya' ni șadrıñ żıddıdır

Hem dahi iskemle vü kürsì demekdir zīirgāh

5 Pādişāh-1 'ālemiñ nāsa ' ināyet etdigi

Bāberāt-1 şehriyārī dirlige de nān-1 şāh

Şol küçük ev kim yapılmış Ḥażret-i Ya' ḳūb içün

Külbe-i aḥzān'dır pirāylardı anda āh

Tekye-āsā hem dahi celb-i rıẓā-yı Ḥaḳk içün

Yapılan beytiñ adı olmuş işitdim ḩāniḳāh

Çāşt ḳuşluḳ vaḳtidir hem öyle vaḳti nīmrüz

Şām ahş̧am şeb gece vaḳt-i seḥerdir bāmgāh

Tañ yerine dendi vāretgāh $u$ aydın rūşenā

Hem sepīīi aḳlı̣̣ oldu ṣubḥ-1 kāžibdir pegāh

10 Otlag̉a denmiş çerāmīn u çerāgāh öyledir

Hem denilmişdir ota fāfïr ${ }^{43}$ mānend-i giyāh

De kulūte ḳavug̣a piçān ṣar lāmā șarık

Ḳoy başa ber ser benih ḳalpaḳ demekdir hem kulāh

Tuhfe-i Vehbì de yazmış "Cām rā ber seng zen"

\footnotetext{
42 Metinde “"ِوب اندين" şeklinde yazılıdır.

${ }^{43}$ Metinde “فاقير” şeklinde yazılıdır.
} 
$146^{*}{ }^{\text {TAED }} 55$

Mehmet Akif GÖZiTOK

Tevbe eyle demeden olmuş kināye șuç gunāh

Mescide mezgit denür bāng-1 namāz olmuş ežān

Dendi guldeste mināre adına dahi munāh

14 Fā' ilātün fă‘ ilātün ben ṣıg̉ındım Tañrı’ya

Var mıdır ḥaṣn-1 Hudā'dan özge bir cā-yı penāh

\section{Sonuç}

Farsça-Türkçe manzum sözlüklerimizden olan ve Çelebizade Ali İlmî Efendi tarafından 1224 (m. 1809-10) yllında telif edilen Nazm-ı Bedî, 115 beyitlik bir mukaddime, 710 beyite tekabül eden 68 kıt'a, 104 ve 12 beyitlik 2 mesnevi ve 9 beyitlik bir hatime olmak üzere toplamda 946 beyitten müteşekkildir. Eserde 1993 adet isim, fiil ve sıfat; 176 adet deyim; 97 adet çekimli isim ve fiil bulunmaktadır. Eserin toplam kelime sayısı 2266'dır. Eser yazılırken Mütercim Asım Efendi'nin telif-tercüme eseri Tibyân-ı Nafì der-Tercüme-i Burhân-ı Kat'ı ve Şeyhulislam Esad Efendi'nin Lehcetü'l-Lügat isimli mensur sözlüklerinden derlemeler yapılmış, eserin kelime kadrosunu oluşturmada bu eserlerden istifade edilmiştir.

Ayrıca eserin incelenmesi ile birlikte manzum sözlüklerin hepsinin sıbyan ve mübtediler için yazılmadığı; yetişkinler için de manzum sözlüklerin yazıldığı sonucuna ulaşılmıştır. Zira eserde içinde nadir kullanılan kelime ve anlamların bulunduğu Burhan-ı Katı'nın; yine Dihudâ'da dahi bulamadığımız kelimeler barındıran Lehcetü'l-Lügat'ın, mübtedinin kullanacağı sözlükler olmadığı kanaatindeyiz. Yine eserde bırakın çocukları, yetişkinler için dahi müstehcen olan pek çok kelimenin kinayeleri ile birlikte gösterildiğine tesadüf edilmektedir.

Bu hâliyle Nazm-ı Bedî’nin, manzum sözlük geleneğimizin önemli bir halkası olduğu aşikârdır. Yine içerdiği kelime sayısı bakımından da benzerlerinin pek çoğundan üstün olması ile önemli bir eser konumundadır.

\section{Kaynaklar}

Ahmet Vefik Paşa (2000). Lehce-i Osmânî. (hz. Recep TOPARLI). Ankara: TDK Yay.

Akçay, A.İ. (2011). Türk edebiyatında manzûm Akâidnâmeler: Inceleme-Metin. Yayımlanmamış Doktora Tezi, Bursa: Uludağ Üniversitesi.

Aksan, D. (2003). Her Yönüyle Dil (Ana Çizgileriyle Dilbilim). Ankara: TDK Yay. 
Akyürek, A.R. (2003). Tuhfe-i Remzî. (hz. Ahmet KARTAL). Ankara: Akçağ Yay.

Alıc1, L. (2004). Tezkirelere Göre Kahramanmaraşlı Divan Şairleri. KSÜ Sosyal Bilimler Dergisi. 1(2), 56-63.

Alıc1, L. ve G. (2014). Maraşlı divan şairlerinden Çelebizade Ali İlmî ve Gebelizade Rahmî. Kahramanmaraş: Noya Medya.

Alparslan, Y. vd., (2009). Türk Edebiyatında Maraşlılar. Kahramanmaraş: Ukde Yay.

Alparslan, Y., Yakar, S. (2011). Eski Maraş'ta Âlim Çıkarmış Aileler. Kahramanmaraş: Ukde Yay.

Beydilli, K. (2009). “Selim III”. DİA, İstanbul, 36, 420-425

Bursalı Mehmet Tahir (1138), Osmanlı müellifleri 1-3. İstanbul.

Çelebizade Ali İlmî. Nazm-ı Bedî, Ankara Üniversitesi DTCF Kütüphanesi No: Üniversite 24.

Çiftçi, C. (2000). Maraşlı Şairler Yazarlar Âlimler. İstanbul: Kitabevi.

Değirmençay, V. (2013). Farsça Şiir Söyleyen Osmanlı Şairleri. Erzurum: Atatürk Üniversitesi Yay.

Duralı, Ş. T. (2013). Omurgasızlaştırılmış Türklük. İstanbul: Dergâh Yay.

Gözitok, M.A. (2014). Deli Birâder Gazâlî ve Miftâhu'l-Hidâye isimli eseri. A. Ü. Türkiyat Araştırmaları Enstitüsü Dergisi [TAED]. 52, 105-139.

İmamoğlu, A. H. (1993). Farsça-Türkçe manzum sözlükler ve Şahidî’nin sözlüğü. Yayınlanmamış Doktora Tezi. Erzurum: Atatürk Üniversitesi Sosyal Bilimler Enstitüsü.

Kılıç, A. (2001). Manzum Sözlüklerimizden Manzûme-i Keskin. Kayseri ve Yöresi Kültür, Sanat ve Edebiyat Bilgi Şöleni Bildiriler (12-13 Nisan 2001),. I, Kayseri, 441-447.

Kılıç, A. (2006). Klâsik Türk Edebiyatında Manzum Sözlük Yazma Geleneği ve Türkçe-Arapça Sözlüklerimizden Sübha-i Sibyan (Metin). Sosyal Bilimler Enstitüsü Dergisi, 20, 65-77.

Kılıç, A. (2006). Türkçe-Arapça Manzum Sözlüklerden Sübha-i T1byân -1- (İnceleme), Turkish Studies. 1(2), 85-104.

Mesud Lutfî Efendi (2013). Tuhfe-i Lutfí. (hz. Ahmet TANYILDIZ). İstanbul: Akademik Kitaplar.

Muhtar, Cemal (1985). İslam'da Sözlük Çalışmaları. Marmara Üniversitesi Illahiyat Fakültesi Dergisi. İstanbul. 3, 363-370.

Mütercim Asım Efendi (2009). Burhan-ı Katı.(hz. Mürsel ÖZTÜRK, Derya ÖRS). Ankara: TDK Yay.

Öbek, A. İ. (2009). Tarihî Türk Sözlükçülüğünde Dönüm Noktası (Büyük) Türk Lügati. Turkish Studies, 4(4), 845-855.

Öz, Y. (2010). Tarih boyunca Farsça-Türkçe sözlükler. Ankara: TDK Yay. 
Özalp, Ö. H. (2010). Tuhfe şârihi Hayatî Ahmed Efendi -şiirleri, kütüphanesi ve Tahâfüt-i Müstahrece'si-. İstanbul: Özgü Yay.

Sünbülzâde Vehbî (1990). Tuhfe-Farsça-Türkçe manzum sözlük-. hz. Turgut Karabey-Numan Külekçi. Erzurum: A.Ü Yay.

Şeyhülislam Mehmed Esad (1999). Lehcetü'l-Lügat. (hz. Ahmet KIRKKILIÇ). Ankara: TDK Yay.

Tuman, Mehmet Nâil (2001). Tuhfe-i Nâilî divan şairlerinin muhtasar biyografileri. (hz. Cemal KURNAZ, Mustafa TATCI). Ankara: Bizim Büro Yay.

Türk Dili ve Edebiyatı Ansiklopedisi (1981). İlmî Ali Efendi (Çelebizâde). 4, İstanbul: Dergâh Yay.

Türk Dünyası Edebiyatçıları Ansiklopedisi (2005). Illmî. 5. Ankara, AKM Yay..

Yurtseven, N. (2003). Türk Edebiyatında Arapça-Türkçe Manzum Lügatler ve Sünbülzâde Vehbî'nin Nuhbe'si. Yayımlanmamış Doktora tezi. Ankara: Ankara Üniversitesi SBE.

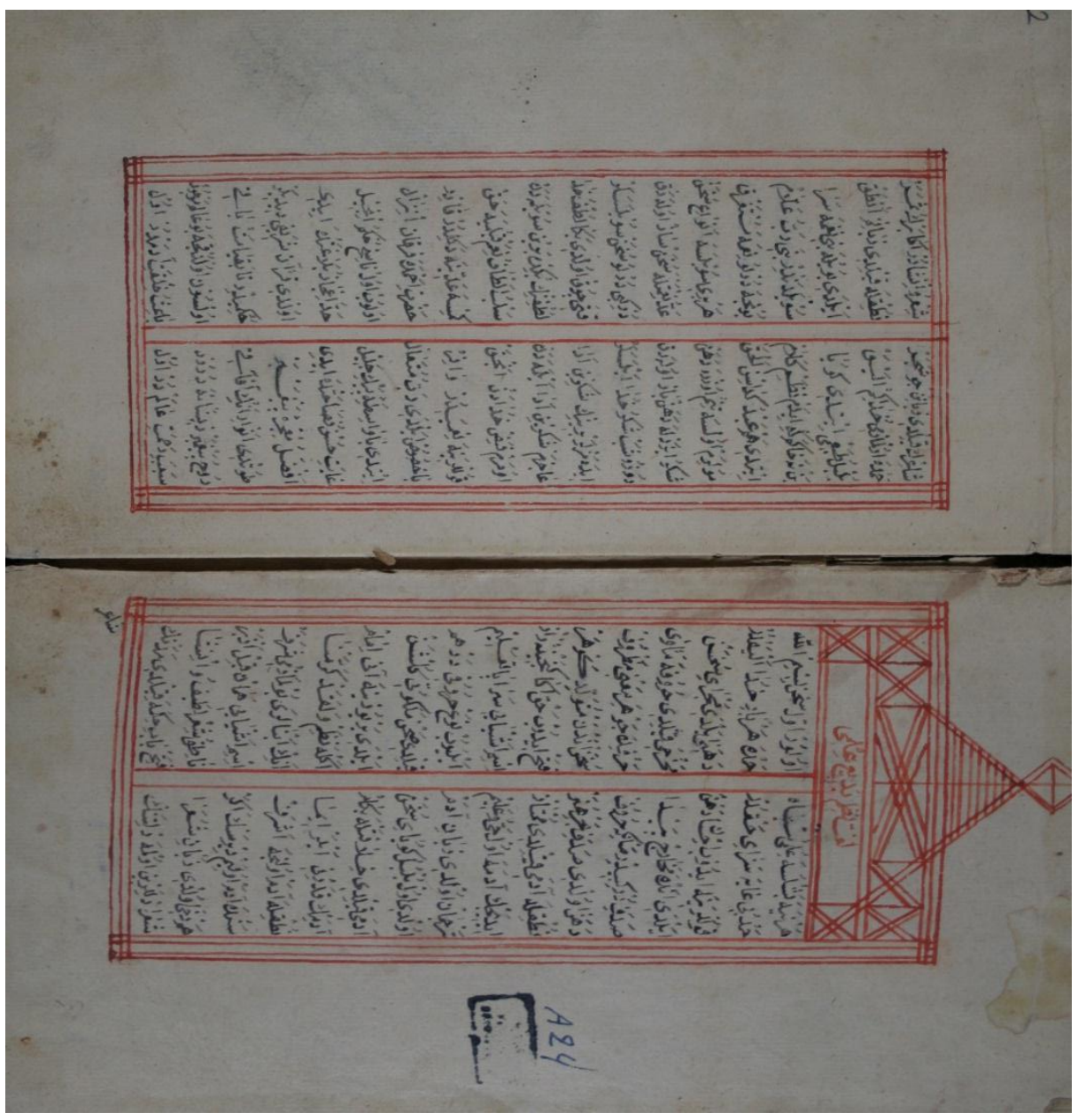

Resim 1: Nazm-ı Bedî Ankara Üniversitesi DTCF Kütüphanesi No: Üniversite 24 1b-2a. 